\title{
Effect of Mixture Proportions on the Drying Shrinkage and Permeation Properties of High Strength Concrete Containing Class F Fly Ash
}

\author{
Pradip Nath* and Prabir Kumar Sarker**
}

Received September 26, 2012/Accepted December 21, 2012

\begin{abstract}
Sustainability of concrete can be improved by using large volume of fly ash as a replacement of cement and by ensuring enhanced durability of concrete. Durability of concrete containing large volume of class F fly ash is dependent on the design of mixture proportions. This paper presents an experimental study on the effect of mixture proportions on the drying shrinkage and permeation properties of high strength concrete containing large volume of local class $\mathrm{F}$ fly ash. Concrete mixtures were designed with and without adjustments in the water to binder ratio $(\mathrm{w} / \mathrm{b})$ and the total binder content to take into account the incorporation of fly ash up to $40 \%$ of total binder. Concretes, in which the mixture proportions were adjusted for fly ash inclusion achieved equivalent strength of the control concrete and showed enhanced properties of drying shrinkage, sorptivity, water permeability and chloride penetration as compared to the control concrete. The improvement of durability properties was less significant when no adjustments were made to the $\mathrm{w} / \mathrm{b}$ ratio and total binder content. The results show the necessity of the adjustments in mixture proportions of concrete to achieve improved durability properties when using class F fly ash as a cement replacement.
\end{abstract}

Keywords: chloride permeability, drying shrinkage, durability, fly ash, sorptivity, water permeability

\section{Introduction}

Although concrete is the most common construction material, its durability is still a major area of study, especially for its use in aggressive environments. In the last few decades, fly ash has been one of the most widely used supplementary cementitious materials in concrete. Its utilization in concrete is valued for its positive contribution in the enhancement of durability properties (Mehta, 1989). The utilization of fly ash also makes construction practice more sustainable by reducing the use of cement, which consumes huge energy in its production and causes about $7 \%$ of all greenhouse gas emissions worldwide (Malhotra, 2002).

Fly ash, a by-product of the combustion of pulverized coal in power plants, acts as a pozzolanic material in concrete. When mixed with Ordinary Portland Cement (OPC) and water, it generates a product similar to that formed by cement hydration, but with a denser microstructure. Properties of fly ash can vary in a wide range depending on the type and the burning process of the coal. Addition of fly ash as a partial replacement of cement can improve the pore structure of concrete by filling pore spaces densely in two ways: as a micro-aggregate and as a pozzolanic product (Poon et al., 2000). The recommended fly ash replacement level for high strength concrete is usually $15-25 \%$ (ACI committee $211,2008)$, but considerable research has been conducted on the properties of concrete using higher proportions of fly ash, such as 30-70\% of the total binder (Carette et al., 1993; Sirivivatnanon et al., 1993; Siddique, 2004). Concrete containing fly ash can exhibit excellent mechanical and durability properties, such as low permeability to chloride ions and other aggressive agents (Langley et al., 1989; Malhotra, 1990); however, poor performances of fly ash concrete have also been reported in literature (Berndt, 2009). The properties of fly ash concrete vary widely due to variable composition of fly ash (Shehata et al., 1999) and varying mixture proportions (Shehata et al., 1999; Burden, 2006).

Design of the mixture proportions of concrete containing fly ash can have a significant effect on the durability properties. For instance, the porosity of concrete depends on whether cement or aggregate is replaced by fly ash (Papadakis, 1999). Poon et al. (2000) found reduced pore diameter and porosity for concrete containing up to $45 \%$ class $\mathrm{F}$ fly ash, but increased porosity for fly ash-cement paste. Thus, the effect of fly ash on concrete's durability properties can vary considerably.

Drying shrinkage of concrete is an important property that affects durability, since cracks developed by shrinkage can increase the permeability of concrete. Few reports have presented the effects of mixture variables on the drying shrinkage of fly ash concrete. Generally, concrete containing fly ash that is mixed with a low water-to-binder ratio $(\mathrm{w} / \mathrm{b})$ and superpasticizer

\footnotetext{
*Research Student, Dept. of Civil Engineering, Curtin University, Western Australia 6845, Australia (Corresponding Author, E-mail: pradip.nath@postgrad.curtin.edu.au)

**Senior Lecturer, Dept. of Civil Engineering, Curtin University, Western Australia 6845, Australia (E-mail: p.sarker@curtin.edu.au)
} 
Table 1. Composition of Cement and Fly Ash

\begin{tabular}{c|c|c|c|c|c|c|c|c|c|c|c|c}
\hline Parameter & $\mathrm{SiO}_{2}$ & $\mathrm{Al}_{2} \mathrm{O}_{3}$ & $\mathrm{Fe}_{2} \mathrm{O}_{3}$ & $\begin{array}{c}\mathrm{SiO}_{2}+\mathrm{Al}_{2} \mathrm{O}_{3} \\
+\mathrm{Fe}_{2} \mathrm{O}_{3}\end{array}$ & $\mathrm{CaO}$ & $\mathrm{MgO}$ & $\mathrm{SO}_{3}$ & $\mathrm{~K}_{2} \mathrm{O}$ & $\mathrm{Na}_{2} \mathrm{O}$ & $\mathrm{P}_{2} \mathrm{O}_{5}$ & Chloride & $\begin{array}{c}\text { Loss } \\
\text { on ignition }\end{array}$ \\
\hline Cement (\%) & 21.10 & 4.70 & 2.70 & 28.50 & 63.60 & 2.60 & 2.50 & - & 0.50 & - & 0.01 & 2.00 \\
\hline Fly ash (\%) & 50.50 & 26.57 & 13.77 & 90.84 & 2.13 & 1.54 & 0.41 & 0.77 & 0.45 & 1.00 & - & 0.60 \\
\hline Class F fly ash ${ }^{\mathrm{a}}(\%)$ & - & - & - & $70.00 \mathrm{~min}$ & $10.00 \mathrm{max}$ & - & $5.00 \mathrm{max}$ & - & - & - & - & $6.00 \mathrm{max}$ \\
\hline
\end{tabular}

${ }^{a}$ ASTM C 618 specification.

shows lower shrinkage than OPC concrete (Atis, 2003; Kumar et al., 2007; Chindaprasirt et al., 2004). On the other hand, an increase of drying shrinkage when fly ash is included in concrete has also been reported (Erdoğan, 1997; Munday et al., 1982). Concrete's durability is governed, to a great extent, by its permeation properties. Fly ash can help in this regard by refining the pores. Naik, Singh and Hossain (1994) found the best performance in terms of air and water permeability with $50 \%$ cement replacement by Class C fly ash. Tasdemir (2003) reported a higher sorptivity coefficient in concrete with $10 \%$ class $\mathrm{C}$ fly ash and a w/b ratio of 0.60 . Conversely, Camoes et al. (2003) obtained a reduced sorption coefficient using $60 \%$ class $\mathrm{F}$ fly ash. As reported in the literature (Cao et al., 1996; Papadakis, 2000), fly ash concretes show superior results to normal cement concrete in chloride ion penetration tests. Both short-term and long-term experiments prove this merit of fly ash (Naik et al., 2003; Thomas and Matthews, 2004); however, the results depend on several factors such as the level of fly ash replacement (Naik et al., 2003), the maturity of concrete during tests and the exposure condition (Thomas and Matthews, 2004).

Nevertheless, it has been recognized that enhanced durability properties of concrete can be achieved by partially replacing cement with fly ash, though the effects vary significantly with the properties of fly ash and the mixture proportions. Improved sustainability of concrete can be achieved when enhanced durability of concrete is ensured by substantial amount of cement replacement with supplementary cementitious materials. However, the enhancement of durability properties of concrete containing large volume of class F fly ash is mainly dependent on the appropriate design of the mixture proportions. This paper studied the effects of different mixture proportions on the drying shrinkage and permeation properties of high strength concrete containing Class F fly ash sourced from Western Australia. Concretes containing $30 \%$ and $40 \%$ of fly ash were proportioned with and without adjustments in the $\mathrm{w} / \mathrm{b}$ ratio and the total binder content. The concrete samples were tested for drying shrinkage, sorptivity, water permeability and chloride ion penetration. The test results were analyzed to determine the effect of different mixture proportions on these properties.

\section{Experimental Details}

\subsection{Materials}

Materials commercially available in Western Australia were
Table 2. Properties of Aggregates

\begin{tabular}{|c|c|c|c|c|}
\hline Properties & \multicolumn{2}{|c|}{ Coarse aggregate } & \multicolumn{2}{|c|}{ Fine aggregate } \\
\hline \multirow{7}{*}{$\begin{array}{c}\text { Sieve } \\
\text { analysis }\end{array}$} & $\begin{array}{l}\text { Sieve } \\
(\mathrm{mm})\end{array}$ & $\begin{array}{l}\text { Percent } \\
\text { passing }\end{array}$ & $\begin{array}{l}\text { Sieve } \\
(\mathrm{mm})\end{array}$ & $\begin{array}{l}\text { Percent } \\
\text { passing }\end{array}$ \\
\hline & 19.00 & 100.0 & 4.75 & 100.0 \\
\hline & 9.50 & 50.0 & 2.36 & 100.0 \\
\hline & 4.75 & 8.9 & 1.18 & 99.7 \\
\hline & & & 0.60 & 77.2 \\
\hline & & & 0.30 & 24.2 \\
\hline & & & 0.15 & 2.7 \\
\hline $\mathrm{FM}^{\mathrm{a}}$ & \multicolumn{2}{|c|}{6.40} & \multicolumn{2}{|c|}{1.96} \\
\hline Sp. Gr. ${ }^{b}$ & \multicolumn{2}{|c|}{2.67} & \multicolumn{2}{|c|}{2.62} \\
\hline Absorption & \multicolumn{2}{|c|}{$0.40 \%$} & \multicolumn{2}{|c|}{$0.99 \%$} \\
\hline Unit Wt. & \multicolumn{2}{|c|}{$1645 \mathrm{~kg} / \mathrm{m}^{3}$} & \multicolumn{2}{|c|}{$1687 \mathrm{~kg} / \mathrm{m}^{3}$} \\
\hline
\end{tabular}

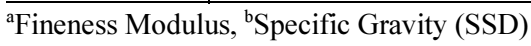

used for the concrete mixtures. Ordinary Portland cement similar to Type I cement (ASTM C150) was used; this is known as General Purpose (GP) Portland cement in Standards Australia (AS 3972). Class F fly ash (ASTM C618) was obtained from a Western Australian power plant. The chemical composition of the cement and fly ash are shown in Table 1. Natural sand of a nominal maximum size of $1.18 \mathrm{~mm}$ was used as fine aggregate. Coarse aggregates comprised a combination of crushed granites with nominal maximum sizes of 7, 10 and $20 \mathrm{~mm}$. Aggregates were tested to ensure that they met Australian standard specifications (AS 2758.1). The results of sieve analysis and physical properties of the aggregates are presented in Table 2 . Normal tap water was used and a naphthalene-based superplasticizer (high range water reducer) was added to enhance workability.

\subsection{Mixture Proportions}

Two series of concrete mixtures were designed according to ACI 211.4R-08 (ACI committee 211, 2008), each comprising two mixtures with fly ash as $30 \%$ and $40 \%$ of the total binder (cement + fly ash), and one control mixture without fly ash (OPC concrete). The first mixture series A was designed by varying both the total binder content and the water binder ratio $(\mathrm{w} / \mathrm{b})$ to achieve similar 28-day compressive strengths. The other mixture series B was designed without altering the proportions of binder content and $w / b$ ratio. Superplasticizer was added to all the 
Table 3. Concrete Mixture Proportions $\left(\mathrm{kg} / \mathrm{m}^{3}\right)$

\begin{tabular}{c|c|c|c|c|c|c}
\hline Mix ID & A00 & A30 & A40 & B00 & B30 & B40 \\
\hline Fly ash & $0 \%$ & $30 \%$ & $40 \%$ & $0 \%$ & $30 \%$ & $40 \%$ \\
\hline Cement & 355 & 308 & 264 & 517 & 362 & 311 \\
\hline Fly ash & 0 & 132 & 176 & 0 & 155 & 207 \\
\hline CA $^{\mathrm{a}}$ & 1185 & 1185 & 1185 & 1185 & 1185 & 1185 \\
\hline Sand & 740 & 661 & 665 & 594 & 570 & 561 \\
\hline Water & 145.5 & 141 & 136.5 & 150 & 150 & 150 \\
\hline $\mathrm{SP}^{\mathrm{b}}$ & 5.11 & 4.77 & 4.75 & 6.77 & 4.80 & 4.24 \\
\hline $\mathrm{w} / \mathrm{b}$ & 0.41 & 0.32 & 0.31 & 0.29 & 0.29 & 0.29 \\
\hline Slump (mm) & 140 & 170 & 185 & 150 & 175 & 160 \\
\hline
\end{tabular}

${ }^{a}$ Coarse Aggregate, ${ }^{b}$ Superplasticizer

mixtures to enhance workability. The mixture proportions of the different batches of concrete are shown in Table 3 .

\subsection{Casting and Preparation of Test Specimens}

Aggregates were prepared to Saturated Surface Dry (SSD) condition. The ingredients were mixed in a laboratory pan mixer. Cylinders of $100 \mathrm{~mm}$ diameter and $200 \mathrm{~mm}$ height were cast for compressive strength, sorptivity, water permeability and chloride permeability tests. For dying shrinkage test, $75 \times 75 \times 280 \mathrm{~mm}$ prisms were cast. Moulds were filled in two equal layers and compacted using a vibrating table. The samples were demoulded after 24 hours of casting and then cured under water at $23^{\circ} \mathrm{C}$ for up to 28 days. At the age of testing, specific specimens were prepared in accordance with the specifications of the particular test.

\section{Test Methods}

Selected durability properties related to permeation of high strength concretes containing fly ash were determined from tests and the properties of concretes with different mixture proportions were compared. The durability of concrete depends on its resistance to ingress of aggressive materials. It was investigated by conducting water sorptivity, water permeability and chloride ion permeability tests. Drying shrinkage was also determined to study the effect of fly ash on the volumetric stability of the concrete samples with different mixture proportions.

\subsection{Compressive Strength}

Cylindrical specimens $(100 \times 200 \mathrm{~mm})$ were tested for compressive strength at the ages of $3,7,28,56,91$, and 210 days. A computerized machine (Controls MCC8) was used to ensure a constant loading rate of $0.33 \mathrm{MPa} / \mathrm{sec}$.

\subsection{Drying Shrinkage}

The drying shrinkage of each mixture was measured as per Standards Australia (AS 1012.13). Three prisms $(75 \times 75 \times 280 \mathrm{~mm})$ were cast with studs placed at both ends at a gauge length of 250 $\mathrm{mm}$. After 24 hours of casting, the samples were demoulded and kept under water until the $7^{\text {th }}$ day, when the initial length was recorded. The samples were then left to dry under laboratory conditions $\left(23^{\circ} \mathrm{C}\right)$. Average length of three specimens was recorded at specified intervals up to 180 days. Drying shrinkage was calculated using the $7^{\text {th }}$-day readings as the reference length.

\subsection{Sorptivity}

The sorptivity test was performed in accordance with ASTM C 1585 (2004). Samples were cured under water up to 28 days and tested at 28 and 180 days after casting. The $50 \mathrm{~mm}$ thick specimen was cut from the top of a $100 \mathrm{~mm}$ diameter cylinder. Two identical specimens were prepared and oven dried until a constant weight was achieved. The cut surface was then put in contact with water after sealing all other surfaces to prevent the evaporation of absorbed water. Change in mass due to sorption was measured at definite intervals for the first six hours. The rate of sorption was calculated as the slope of the best-fit line to the plot of absorption, I (Eq. 1) against the square root of time. The averaged result from the two similar specimens is reported.

$$
I=M_{t} /(A \times D)
$$

where,

$$
\begin{aligned}
A & =\text { Exposed area }\left(\mathrm{mm}^{2}\right) \\
D & =\text { Density of water }\left(\mathrm{gm} / \mathrm{mm}^{3}\right) \\
M_{t} & =\text { Change in mass at time } t(\mathrm{gm})
\end{aligned}
$$

\subsection{Water Permeability}

Water permeability of concrete samples was tested using a method developed by Taywood Engineering Limited (TEL) (Nath and Sarker, 2010). In this test method, water is pressurized through a $50 \mathrm{~mm}$ thick section of a $100 \mathrm{~mm}$ diameter concrete specimen at high pressure (950 KPa, equivalent to $96.9 \mathrm{~m}$ head of water). Specimens were cut from $100 \mathrm{~mm}$ diameter cylinders after 28 days of water curing, and were oven dried until they reached a constant weight. The curved surface of the specimen was coated with epoxy resin while two flat surfaces were kept open. A special rig was used to apply water at high pressure against the bottom face of the specimen. The top face was sealed with a cap fitted with a vertically mounted graduated pipette. Water passing through the concrete specimen rose in the pipette and indicated the rate of flow. The test was continued for 7 days to have a steady rate of flow, and the $7^{\text {th }}$-day results are reported. The permeability coefficient was measured using Darcy's equation in the following form (Eq. 2); the reported result is the average of two identical specimens.

$$
k=(Q \times L) /(A \times H)
$$

where,

$$
\begin{aligned}
A & =\text { Area of specimen }\left(\mathrm{m}^{2}\right) \\
H & =\text { Head of water }(\mathrm{m}) \\
k & =\text { Permeability coefficient }(\mathrm{m} / \mathrm{s}) \\
L & =\text { Depth of specimen }(\mathrm{m}) \\
Q & =\text { Flow rate }\left(\mathrm{m}^{3} / \mathrm{s}\right)
\end{aligned}
$$

\subsection{Rapid Chloride Permeability}

The accelerated chloride penetration parameters of the concrete 
samples were measured as per ASTM C1202-07 (2007). In this method, the likelihood of chloride ion $\left(\mathrm{Cl}^{-}\right)$penetration through concrete is measured in terms of the electrical indication within a six-hour test. A specimen of about $50 \mathrm{~mm}$ thickness was sliced from the top of a $100 \mathrm{~mm}$ diameter cylinder and coated with epoxy resin on its curved surface. In the test cell, the watersaturated specimen was fixed so that one of its flat faces remained exposed to the Sodium Hydroxide solution $(0.3 \mathrm{~N})$ and the other to the Sodium Chloride solution (3\%). An electric potential of 60 volts was maintained across both exposed faces for 6 hours. The chloride penetration of the specimens was expressed as the total charge passed in coulombs during the test period. This is used as an indicative parameter of the chloride permeability of concrete. An averaged result from two similar specimens is reported.

In addition, the resistivity of the concrete was determined by using the initial current induced for 60 volt potential (Dinakar et al., 2008). Ohm's law (Eq. 3) was used for calculating resistance $(R)$; then resistivity could be calculated by Eq. (4):

$$
R=V / I
$$

$$
\text { Resistivity }=(R \times A) / l
$$

where,

$$
\begin{aligned}
A & =\text { Area of the specimen }\left(\mathrm{m}^{2}\right) \\
I & =\text { Initial current } \\
l & =\text { Thickness of the specimen }(\mathrm{m}) \\
R & =\text { Resistance } \\
V & =\text { Voltage }
\end{aligned}
$$

\section{Results and Discussion}

\subsection{Workability of Fresh Concrete}

The workability of the fresh concrete mix was measured by slump test, according to Australian standards (AS 1012.3.1). The average slump and amounts of superplasticizer used are shown in Table 3 and Fig. 1. The fly ash concretes were more workable in terms of slump than the control concretes in both series of

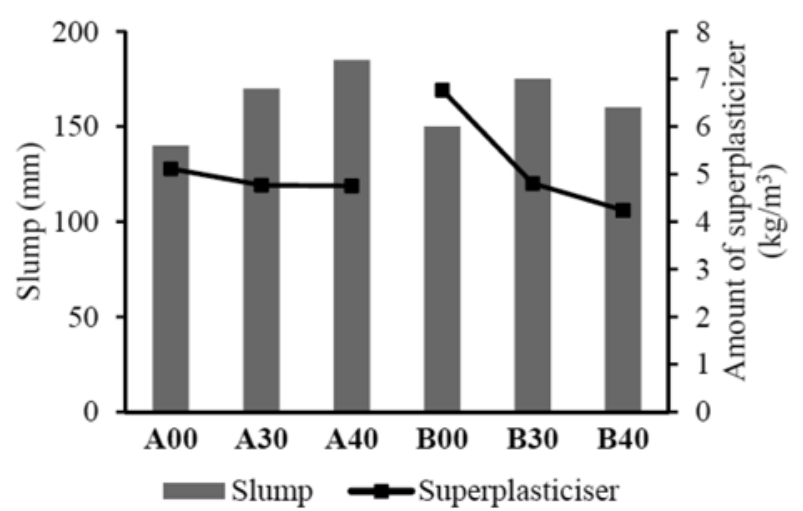

Fig. 1. Slump of Different Concrete Mixtures and Corresponding Amount of Superplasticizer mixtures. In series A, although the control mix A00 had a slightly higher amount of superplasticizer, it showed less workability than fly ash concretes (A30 and A40). Slump value increased with the increase of fly ash content in concretes having a similar amount of superplasticizer. This is because the spherical shape of fly ash particles offers less resistance to movement than the angular cement particles. This advantage of fly ash was taken into account when designing the concretes of series B, by reducing the amount of superplasticizer with increasing amount of fly ash in the concrete; the fly ash concretes still achieved slightly higher slump than that of the control concrete (B00). This proves that concrete containing fly ash requires less superplasticizer to achieve a similar workability of Ordinary Portland cement concrete. The slump of the mix with $40 \%$ fly ash (B40) decreased slightly compared with the mix containing $30 \%$ fly ash (B30); however, the slump drop was $9 \%$ for a superplasticizer drop of $12 \%$.

\subsection{Compressive Strength}

Compressive strength is an indicative characteristic of concrete that allows us to envisage other properties. Generally, enhanced durability properties can be obtained with concretes of higher compressive strength. The mixes prepared in this study were designed to achieve a 28-day compressive strength of over 50 $\mathrm{MPa}$, as recommended by AS 3600 (2009) for the most severe environments. The compressive strength results from 3 days to 210 days are shown in Fig. 2. The initial strength developments

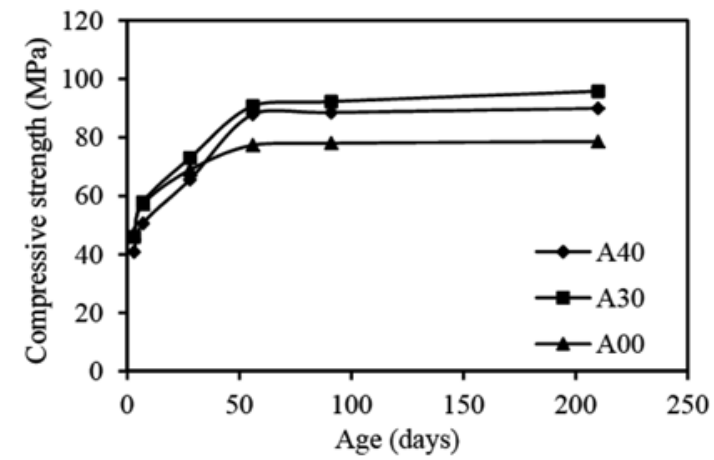

(a)

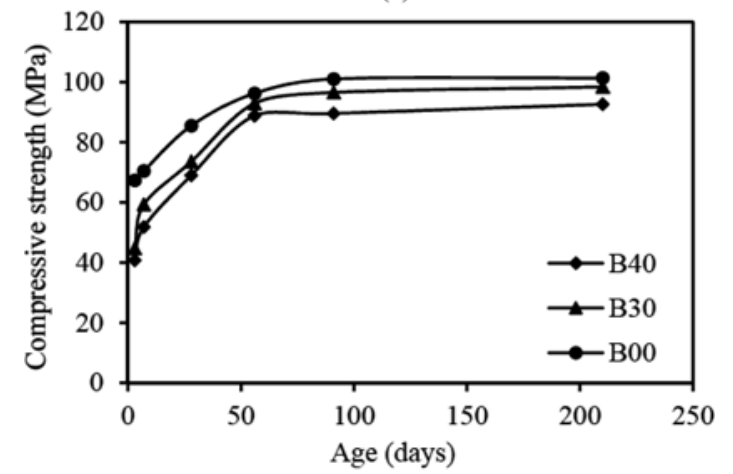

(b)

Fig. 2. Compressive Strength Development of Concretes in: (a) Series A, (b) Series B 


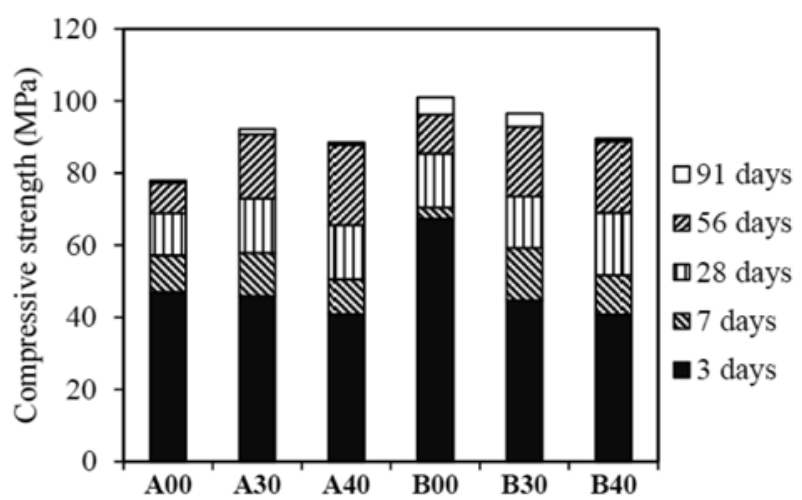

Fig. 3. Compressive Strength Development Trend Over Time

of all the concretes are compared in Fig. 3.

The results indicate that concretes that incorporated fly ash had decreased strengths at an early age than the control concrete, but at later stages they have either gained more strength (series A) than, or reached very close (series B) to, the control concrete's strength, depending on the mixture proportions. The fly ash concretes of series A (A30 and A40) in which w/b ratio and total binder content were varied from those of control concrete (A00) to adjust for the partial inclusion of fly ash as a binder, gained similar strength within $\pm 6 \%$ of the control concrete at 28 days. At 56 days, both fly ash concretes displayed more than $110 \%$ of the control concrete's strength.

On the other hand, the strength of the fly ash concretes of series B (B30 and B40) decreased when fly ash was used in place of cement with constant $\mathrm{w} / \mathrm{b}$ ratio and amount of total binder. They achieved more than $80 \%$ of the control concrete's strength at 28 days, and reached $92 \%$ and $96 \%$ of the control concrete's strength at 56 days, for $40 \%$ and $30 \%$ fly ash content respectively.

Generally, concrete with $30 \%$ fly ash showed higher strength gains than that of $40 \%$ fly ash. The rate of strength development between 28 and 56 days was higher for the fly ash concretes than for their controls in both series A and B. From Fig. 3 it is clear that a significant part of the strength of fly ash concretes developed during the period of 28 to 56 days. This reveals the notable strength development capability of fly ash concrete due to pozzolanic reaction after 28 days, in contrast to normal cement concrete. The trend of strength development in the fly ash concretes is in accord with that reported in the literature (Poon et al., 2000; Siddique, 2004; Papadakis and Tsimas, 2002).

\subsection{Drying Shrinkage}

The effect of the incorporation of fly ash in concrete on the drying shrinkage of series A and B is shown in Fig. 4. It can be observed from the figures that all the concrete samples shrank most within 56 days of casting, after which the rate of shrinkage decreased markedly. The values of shrinkage in all the specimens at 56 days were well below 1000 microstrain as specified by Standards Australia for both normal and special classes of

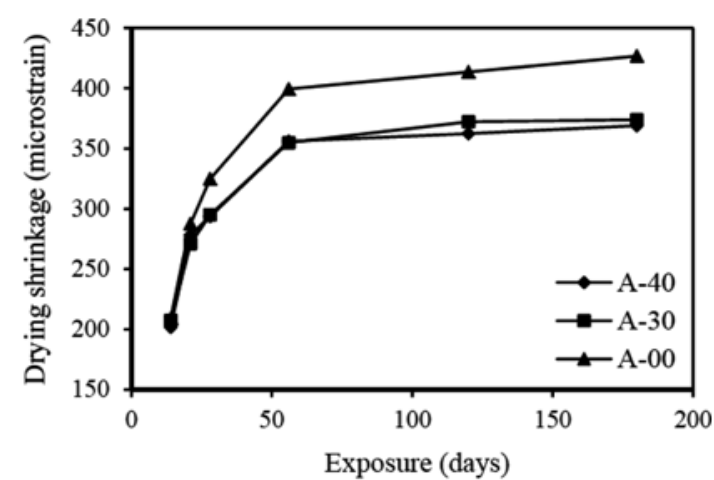

(a)

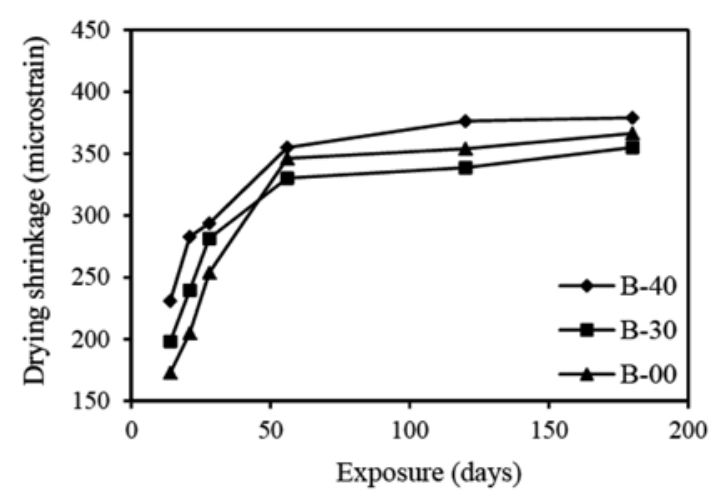

(b)

Fig. 4. Effect of Fly Ash on Drying Shrinkage of Concretes in: (a) Series A, (b) Series B

concrete (AS 1379).

Concretes incorporating fly ash experienced less drying shrinkage than the control concrete when they were designed with variable $\mathrm{w} / \mathrm{b}$ ratios and variable total binder contents (series A), because they had a lower w/b ratio. The shrinkage of fly ash concretes of series A did not vary significantly from that of the control concrete for the first 21 days (Fig. 4(a)), but their rate had dropped by at least $10 \%$ of the control concrete's value at 56 days. At 180 days, the concrete containing $40 \%$ fly ash (A40) achieved slightly lower shrinkage than the concrete containing $30 \%$ fly ash (A30).

In Series B, the shrinkage values of B30 and B40 were affected by the inclusion of fly ash in the concretes; their shrinkage values were higher than that of the control concrete (B00) until 28 days (Fig. 4(b)). After that, the rate of shrinkage decreased for the fly ash concretes, reaching a value equivalent to that of the control concrete at 56 days. The concrete with $30 \%$ fly ash showed less shrinkage than both the $40 \%$ fly ash sample and the control concrete. Fly ash concrete requires less water to produce an effect similar to cement concrete (Jiang and Malhotra, 2000). Because of the unaltered water content in all the mixtures of series B, those concretes incorporating fly ash had a relatively higher amount of free water than the concrete containing only OPC; hence, drying shrinkage increased with the increase of fly ash from $30 \%$ to $40 \%$ of total binder. However, the shrinkage of the fly ash concretes was within only $\pm 4 \%$ of the control 
concrete's value after 56 days. Although this is a reasonable result considering the high strength of concretes, it signifies the need for adjustment in proportions when the mix incorporates fly ash as a partial replacement of cement.

\subsection{Sorptivity}

The sorptivity test is a measure of concrete's behavior in the capillary permeation of water. Samples cured in water for 28 days (curing regime I) and 7 days (curing regime II) were tested at 28 and 180 days after casting. The initial sorptivity coefficients of series A and series B at 28 and 180 days were compared for both curing regimes I and II, as shown in Fig. 5.

In general, the results indicate that the incorporation of fly ash resulted in less sorption than that of the control concrete at the early age of 28 days in both series. The values of the sorptivity coefficients of fly ash concretes were less than $129.1 \times 10^{-4} \mathrm{~mm} / \mathrm{s}^{1 / 2}\left(0.1 \mathrm{~mm} / \mathrm{min}^{1 / 2}\right)$, which is rated as a 'very good' performance according to Papworth and Grace (1985). The reduction in sorptivity was higher when the inclusion of fly ash was balanced by a reduced $\mathrm{w} / \mathrm{b}$ ratio and higher total binder content (series A). Generally, sorptivity decreased with an increase in the proportion of fly ash, in both series. At 28 days, mix A40 of curing regime I (28 days' water curing) showed

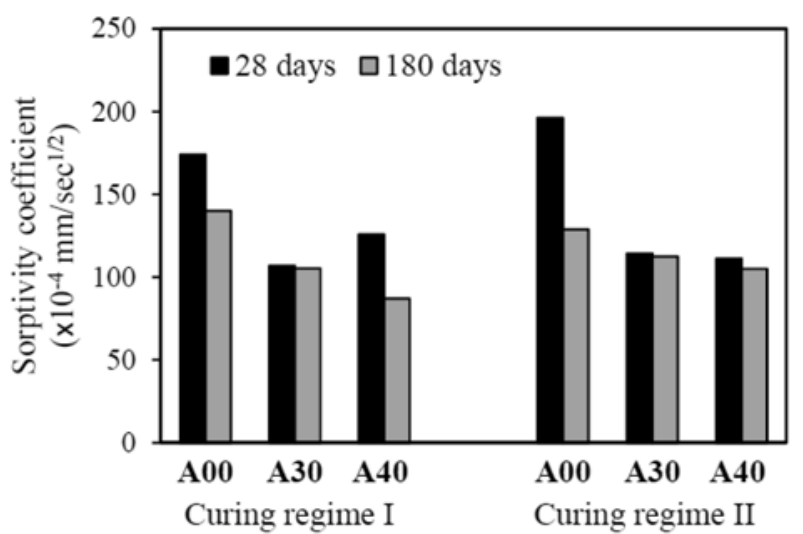

(a)

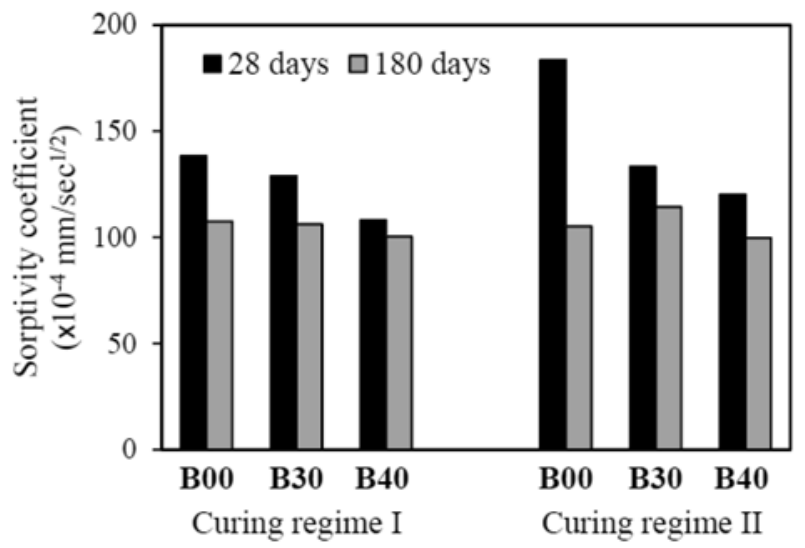

(b)

Fig. 5. Comparison of Sorptivity Coefficients of Concretes in: Series A, (b) Series B slightly higher absorption than mix A30; however, after 180 days, the sorptivity of mix A40 reached $17 \%$ lower than that of mix A30. At 180 days, sorptivity dropped by $25 \%$ and $37 \%$ of the control concrete's value for A30 and A40 respectively.

Inclusion of fly ash with constant $\mathrm{w} / \mathrm{b}$ and constant total binder content in the mix (series B) decreased absorption slightly (Fig. 5(b)). The sorptivity of the fly ash concretes in series B at 28 days decreased up to $21 \%$ of the control concrete; in contrast, sorptivity decreased up to $38 \%$ in the series A samples. After 180 days, the rate of sorptivity of fly ash concrete tended to be similar to that of the control concrete.

The rate of sorption was influenced by the initial curing period, reducing as the curing was extended from 7 to 28 days. Fly ash concretes that were cured for 7 days (curing regime II) also reached lower sorption than their control concretes at both 28 days and 180 days; however, their sorptivity coefficients were higher than those of the corresponding concretes cured for 28 days (curing regime I). These results support the requirement for intensive curing of fly ash concrete to achieve enhanced impermeability (Khan and Ayers, 1993; Ramezanianpour and Malhotra, 1995).

Fly ash contributes to the reduction in absorption in two ways: by filling the micro-pores through pozzolanic reaction and by acting as a micro-aggregate (Poon et al., 2000). With this dual action, fly ash blocked the capillary pore systems in the concrete and improved the resistance to permeation from as early as 28 days (Marsh et al., 1985). In addition, modification of the mixture proportions to account for the inclusion of fly ash helped reduce the sorption further as compared to the control concrete of similar grade.

\subsection{Water Permeability}

Water permeability was tested by measuring the uniaxial flow of highly pressurized water passing through the concrete sample. Water permeability coefficients for different mixes at 28 days and 180 days are compared in Fig. 6. The results generally indicate a better performance of the fly ash concretes that were adjusted to cope with cement replacement. In series A, similar

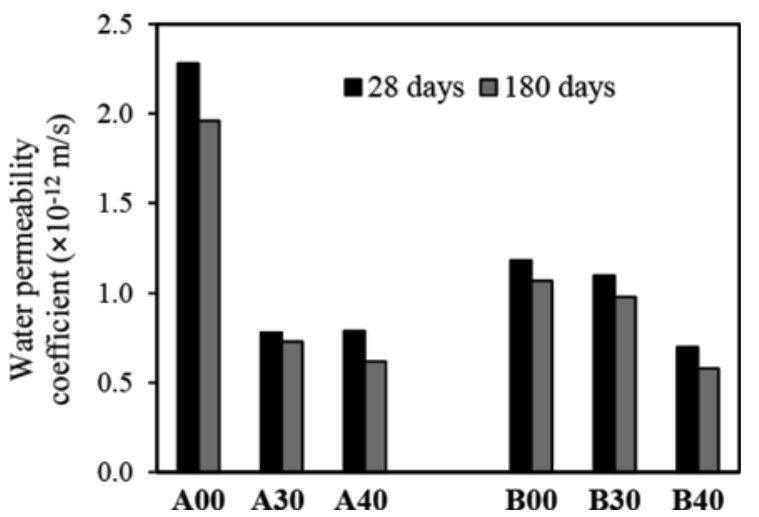

Fig. 6. Comparison of Water Permeability of Concretes in Series A and $\mathrm{B}$ 


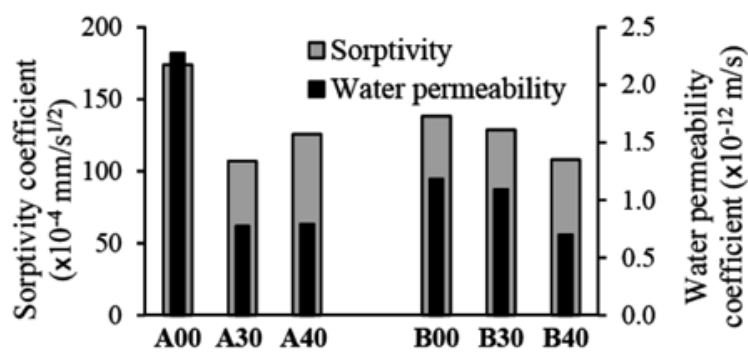

Fig. 7. Comparison of Sorptivity and Water Permeability at 28 Days

grades of fly ash concretes demonstrated significant resistance to water permeation, while the fly ash concretes of series B restricted the flow of water to a lesser extent. Water permeability coefficients of mixtures $\mathrm{A} 30$ and A40 at 28 days were about $65 \%$ less than that found in the control concrete (A00). In series $\mathrm{B}$, the water permeability coefficients of mixtures B30 and B40 were $7 \%$ and $40 \%$ less, respectively, than that of B00. The low water permeability of the fly ash concretes of series A is mainly because of their lower $w / b$ ratios as compared to that of the control concrete mix.

The values of the permeability coefficients of all the fly ash concretes except B30 at 28 days were below $10^{-12} \mathrm{~m} / \mathrm{s}$, which indicate a 'very good' performance according to Papworth and Grace (1985). Nevertheless, mix B30 was in the margin of that limit at 28 days, and achieved the 'very good' level of performance at 180 days.

At 180 days, permeability decreased for every mix. However, concretes with $40 \%$ fly ash in both series achieved the most reductions from 28 -day values: $21 \%$ and $17 \%$ for A40 and B40 respectively. This indicates the positive effect of fly ash on the decrease of permeability of concrete, and is due to the late reaction of fly ash that helps reduce pore volume as well as block pores (Marsh et al., 1985).

Results of the 28-day sorptivity tests are compared with the results of water permeability at the same age in Fig. 7. The comparison shows similar trends for both series of concretes. This implies the similitude of the two different forms of water penetration in concrete: capillary suction and the penetration of water under pressure.

\subsection{Rapid Chloride Permeability}

An accelerated chloride permeability test was conducted at 28 and 180 days. The total charges passed, which indicate the level of chloride ion penetration through the concretes, were compared with the limits suggested in ASTM C1202-07 (2007), and are shown in Fig. 8. The fly ash concretes achieved better resistance to chloride permeation than the control concretes in both series. Chloride penetrability decreased with the increase of fly ash in the mixtures. At 28 days of age, fly ash concretes achieved a 'low' level of chloride ion penetration, compared to a 'moderate' level in the corresponding controls. At 180 days, the resistance to chloride ion penetration for fly ash concretes improved, reaching less than 1000 coulombs of total charge passed: assessed as 'very

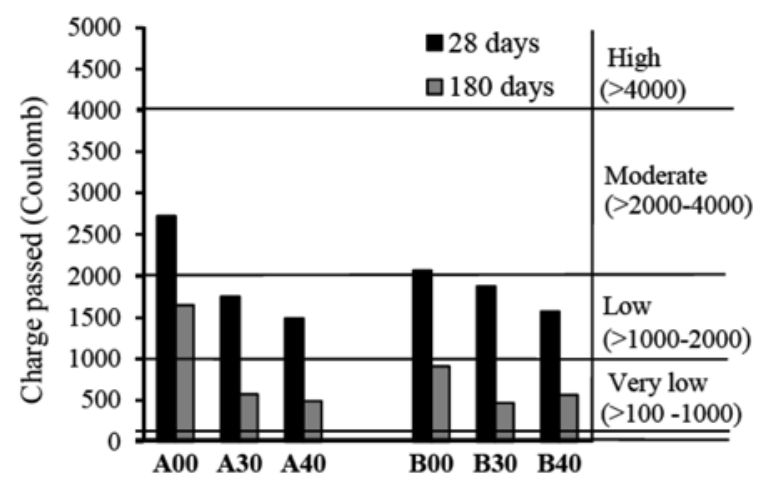

Fig. 8. Chloride Permeability Levels of Concretes in Series A and B as Per ASTM C1202-07

low' chloride permeability by ASTM C1202-07 (2007).

In series A, the fly ash concrete samples showed significantly less chloride ion penetration compared with the control concrete at the early age of 28 days. Mixtures A30 and A40 achieved 35\% and $45 \%$ less charge passed respectively than the control concrete (A00), and this further reduced to $65 \%$ and $70 \%$ respectively at 180 days. In series $\mathrm{B}$, replacing cement partially with fly ash while keeping the same $\mathrm{w} / \mathrm{b}$ ratio improved the resistance to chloride ion penetration, but to a lesser extent than in series A. At 28 days, the charges passed through B30 and B40 were $10 \%$ and $24 \%$ less respectively, than in the control concrete (B00), and reduced to $48 \%$ and $38 \%$ respectively at 180 days. The resistance to chloride ion penetration improved with aging in all the mixes, but the fly ash concretes improved to a higher degree than the control concrete. For instance, at 180 days, the total charge passed reduced by $68 \%$ of the corresponding 28 -day values in the fly ash concretes of series $\mathrm{A}$, while there was only a $40 \%$ reduction in the control concrete A00. At 180 days, B30 and B40 achieved over $64 \%$ reduction of charge passed, while B00 achieved $56 \%$ reduction. The results are in accord with those reported in the literature (Malhotra, 1990; Sengul et al., 2005) and support the chloride binding capacity of fly ash in concrete, as chloride ion penetration depends on the chloride binding capacity of the constituent materials of the concrete.

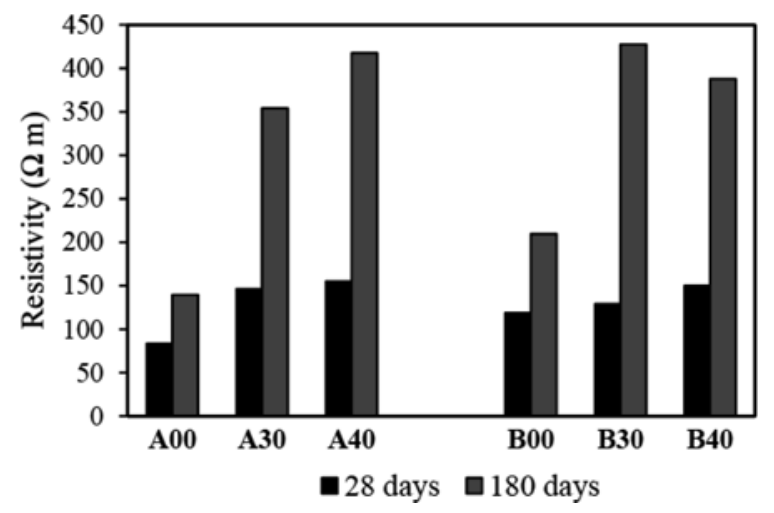

Fig. 9. Resistivity Results of Concretes in Series A and B 
The resistivity values calculated from the initial current at $60 \mathrm{~V}$ potential show a trend similar to the total charge (Fig. 9). It indicates a higher resistivity of fly ash concretes than that of the control OPC concrete. Higher resistance caused reduced chloride penetration in fly ash concretes. There was significant increase in the resistivity values of the fly ash concrete samples at 180 days, compared to those at 28 days.

\section{Conclusions}

High-strength concretes designed with $30 \%$ and $40 \%$ cement replacement by class F fly ash were studied. Mixtures were designed with and without adjustments in the w/b ratio and the total binder content, to account for the inclusion of fly ash. The effect of these adjustments on the drying shrinkage and permeation properties of concretes was investigated. The following conclusions are drawn from the test results:

1. In general, the inclusion of fly ash in concrete improved its workability. Fly ash concretes required less superplasticizer than the corresponding OPC concretes for the same value of slump.

2. The 28-day compressive strength dropped when cement was partially replaced by fly ash without adjusting the w/b ratio and the binder content. Similar 28-day strength as the control concrete was achieved in fly ash concrete when the mixture proportions were adjusted. Noticeable strength development continued up to 56 days in the fly ash concretes.

3. Fly ash concrete achieved reduced drying shrinkage than the control concrete of similar grade when the $\mathrm{w} / \mathrm{b}$ ratio and the binder content were adjusted to take into account the inclusion of fly ash. Inclusion of fly ash without necessary adjustment in the mixture proportions may not result in reduced drying shrinkage.

4. Fly ash concretes achieved less sorption than the control concretes, however significant reduction was observed when adjustments were made in the mixtures. Sufficient curing is important for durability, as curing for 28 days gave less sorptivity than those cured for 7 days.

5. Incorporation of fly ash reduced the water permeability of concrete at an early age and permeability further decreased at six months. The decrease in water permeability of the fly ash concretes was higher for the mixtures with adjusted $\mathrm{w} / \mathrm{b}$ ratios and binder contents.

6. Fly ash concretes yielded lower chloride ion penetration as compared to control concrete at both 28 and 180 days. The resistance of fly ash concretes having adjusted $\mathrm{w} / \mathrm{b}$ ratios and binder contents was better than that of the mixtures having no adjustments.

Over all, the results indicate the significance of the adjustment of mixture proportions when using fly ash as a replacement of cement. Inclusion of fly ash with adjustments in the mixture proportions of concrete increased strength, reduced drying shrinkage and improved the permeability properties of concrete significantly. Hence, when replacing cement with fly ash, adjustments in the mixture proportions to achieve similar strength of the control OPC concrete eventually yields better durability properties.

\section{Acknowledgements}

The authors wish to acknowledge the support from the Centre for Sustainable Resource Processing (CSRP) and the assistance of SGS Australia Pty Ltd in carrying out some of the tests described in this paper. The help of the concrete laboratory staff of Curtin University is gratefully acknowledged.

\section{References}

ACI committee 211. (2008). Guide for selecting proportions for highstrength concrete using Portland cement and other cementitious materials, Report No.: ACI 211.4R-08, American Concrete Institute, USA.

AS 1012.13 (1992). Methods of testing concrete - Method 13: Determination of the drying shrinkage of concrete samples prepared in the field or in the laboratory, Standards Australia, <http://www. saiglobal. com $>$ (Retrieved 12-04-2009).

AS 1012.3.1 (1998). Methods of testing concrete - Method 9: Determination of properties related to the consistency of concrete Slump test, Standards Australia, <http://www.saiglobal.com> (Retrieved 12-04-2009).

AS 1379 (2007). Specification and supply of concrete, Standards Australia, <http://www.saiglobal.com> (Retrieved 12-04-2009).

AS 2758.1 (1998). Aggregates and rock for engineering purposes Part 1: Concrete aggregates, Standards Australia, <http://www.sai-global. com $>$ (Retrieved 12-04-2009).

AS 3600 (2009). Concrete structures, Standards Australia, <http:// www.saiglobal.com $>$ (Retrieved 20-11-2009).

AS 3972 (1997). Portland and blended cements, Standards Australia, $<\mathrm{http}: / /$ www.saiglobal.com $>$ (Retrieved 12-04-2009).

ASTM C618 (2008). Standard specification for coal fly ash and raw or calcined natural pozzolan for use in concrete, ASTM Standards, $<$ http://specs4.ihserc.com> (Retrieved 07-04-2009).

ASTM C1202-07 (2007). Standard test method for electrical indication of concrete's ability to resist chloride ion penetration, ASTM Standards, $<$ http://specs4.ihserc.com> (Retrieved 07-04-2009).

ASTM C1585-04 (2004). Standard test method for measurement of rate of absorption of water by hydraulic cement concretes, ASTM Standards, $<$ http://specs4.ihserc.com $>$ (Retrieved 07-04-2009).

Atis, C.D. (2003). "High-volume fly ash concrete with high strength and low drying shrinkage." J. Mater. Civ. Eng., Vol. 15, No. 2, pp. 153156.

Berndt, M.L. (2009). "Properties of sustainable concrete containing fly ash, slag and recycled concrete aggregate." Const. Build. Mater., Vol. 23, pp. 2606-2613.

Burden, D. (2006). The durability of concrete containing high levels of fly ash, MSc Thesis, University of New Brunswick, Canada.

Camoes, A., Aguiar, B., and Jalali, S. (2003). "Durability of low cost high performance fly ash concrete." Proc., International Ash Utilization Symposium, Centre for Applied Energy Research, University of Kentuky, USA.

Cao, H.T., Bucea, L., Meek, E., and Yozghatlian, S. (1996). Formulation and durability of fly ash blended cement, CSIRO Report BRE 030, June. 
Carette, G., Bilodeau, A., Chevrier, R. L., and Malhotra, V. M. (1993). "Mechanical properties of concrete incorporating high volumes of fly ash from sources in the U.S." ACI Mater. J., Vol. 90, No. 6, pp. 535-544.

Chindaprasirt, P., Homwuttiwong, S., and Sirivivatnanon, V. (2004). "Influence of fly ash fineness on strength, drying shrinkage and sulfate resistance of blended cement mortar." Cem. Concr. Res., Vol. 34, No. 7, pp. 1087-1092.

Dinakar, P., Babu, K. G., and Santhanam, M. (2008). "Durability properties of high volume fly ash self compacting concretes." Cem. Concr. Comp., Vol. 30, No. 10, pp. 880-886.

Erdoğan, T. Y. (1997). Admixtures for concrete, Middle East Technical University Press Ankara, Turkey.

Jiang, L. H. and Malhotra, V. M. (2000). "Reduction of water demand of non-air-entrained concrete incorporating large volumes of fly ash." Cem. Concr. Res., Vol. 30, No. 11, pp. 1785-1789.

Khan, M. S. and Ayers, M. E. (1993). "Curing requirements of silica fume and fly ash mortars." Cem. Concr. Res., Vol. 23, No. 6, pp. 1480-1490.

Kumar, B., Tike, G. K., and Nanda, P. K. (2007). "Evaluation of properties of high-volume fly-ash concrete for pavements." J. Mater. Civ. Eng., Vol. 19, No. 10, pp. 906-911.

Langley, W. S., Carette, G. G., and Malhotra, V. M. (1989). "Structural concrete incorporating high volumes of ASTM class F fly ash." $A C I$ Mater. J., Vol. 86, No. 5, pp. 507- 514.

Malhotra, V. M. (1990). "Durability of concrete incorporating highvolume of low-calcium (ASTM class F) fly ash." Cem. Concr. Comp., Vol. 12, No. 4, pp. 271-277.

Malhotra, V. M. (2002). "Introduction: Sustainable development and concrete technology." Conc. Int., Vol. 24, No. 7, p. 22.

Marsh, B. K., Day, R. L., and Bonner, D. G. (1985). "Pore structure characteristics affecting the permeability of cement paste containing fly ash." Cem. Concr. Res., Vol. 15, No. 6, pp. 1027-1038.

Mehta, P. K. (1989). "Pozzolanic and cementitious by-products in concrete - Another look." Proc., $3^{\text {rd }}$ International Conference on the use of Fly Ash, Silica Fume, Slag and Natural Pozzolans in Concrete, ACI SP-114, Trondheim, Norway, p. 1.

Munday, J. G. L., Ong, L. T., Wong, L. B., and Dhir, R. K. (1982). "Load independent movements in opc/pfa concrete." Proc., Proceedings of International Symposium on the Use of PFA in Concrete, 1, Leeds, UK, pp. 243-253.

Naik, T. R., Ramme, B. W., Kraus, R. N., and Siddique, R. (2003). "Long-term performance of high-volume fly ash pavements." $A C I$ Mater. J., Vol. 100, No. 2, pp. 150-155.

Naik, T. R., Singh, S. S., and Hossain, M. M. (1994). "Permeability of concrete containing large amounts of fly ash." Cem. Concr. Res., Vol. 24, No. 5, pp. 913-922.

Nath, P. and Sarker, P. (2010). "Resistance to permeation of high strength concrete containing fly ash." Proc., $2^{\text {nd }}$ International Symposium on Life-cycle Civil Engineering, Taiwan Tech., Taipei, Taiwan, pp. 597602.

Papadakis, V. G. (1999). "Effect of fly ash on Portland cement systems Part I. Low-calcium fly ash." Cem. Concr. Res., Vol. 29, No. 11, pp. 1727-1736.

Papadakis, V. G. (2000). "Effect of supplementary cementing materials on concrete resistance against carbonation and chloride ingress." Cem. Concr. Res., Vol. 30, No. 2, pp. 291-299.

Papadakis, V. G. and Tsimas, S. (2002). "Supplementary cementing materials in concrete: Part I. Efficiency and design." Cem. Concr. Res., Vol. 32, No. 10, pp.1525-1532.

Papworth, F., and Grace, W. (1985). "Designing for concrete durability in marine environs." Proc., Concrete 85 Conference, Concrete Institute Australia, Brisbane, Australia.

Poon, C. S., Lam, L., and Wong, Y. L. (2000). "A study on high strength concrete prepared with large volumes of low calcium fly ash." Cem. Conc. Res., Vol. 30, No. 3, pp. 447-455.

Ramezanianpour, A. A., and Malhotra, V. M. (1995). "Effect of curing on the compressive strength, resistance to chloride-ion penetration and porosity of concretes incorporating slag, fly ash or silica fume." Cem. Concr. Comp., Vol. 17, No. 2, pp. 125-133.

Sengul, O., Tasdemir, C., and Tasdemir, M. A. (2005). "Mechanical properties and rapid chloride permeability of concretes with ground fly ash." ACI Mater. J., Vol. 102, No. 6, pp. 414-421.

Shehata, M. H., Thomas, M. D. A., and Bleszynski, R. F. (1999). "The effects of fly ash composition on the chemistry of pore solution in hydrated cement pastes." Cem. Concr. Res., Vol. 29, No. 12, pp. 1915-1920.

Siddique, R. (2004). "Performance characteristics of high-volume Class F fly ash concrete." Cem. Conc. Res., Vol. 34, No. 3, pp. 487-493.

Sirivivatnanon, V., Cao, H.T., Baweja, D., and Nelson, P. (1993). "Properties of high volume fly ash concrete." Proc., Concrete Institute of Australia $16^{\text {th }}$ Biennial Conference, Melbourne, Australia, pp. 256273.

Tasdemir, C. (2003). "Combined effects of mineral admixtures and curing conditions on the sorptivity coefficient of concrete." Cem. Concr. Res., Vol. 33, No. 10, pp. 1637-1642.

Thomas, M. D. A. and Matthews, J. D. (2004). "Performance of pfa concrete in a marine environment - 10 year results." Cem. Concr. Comp., Vol. 26, No. 1, pp. 5-20. 